\title{
Inácio de Loyola: “Experiência-modelo” e educação à liberdade
}

Ignatuis of Loyola:

“Experience-model” and education tu freedom

Paulo Roberto de Andrada Pacheco*

\section{Resumo}

Partindo do conceito de "experiência-modelo", pretendemos mostrar como o projeto educacional da Antiga Companhia de Jesus (1540-1773), especificamente o aspecto denominado educação à liberdade, estava fundado sobre a vida de Inácio oferecida como modelo para imitação. Baseamo nos num estudo historiográfico de algumas fontes da Companhia e utilizamos como modelo compreensivo a proposta que estabelece a unidade espiritual-institucional-filosófico-retórica da experiência do jesuíta como perspectiva de análise. Chegamos a identificar a eficácia deste projeto pedagógico na maneira como o jesuíta apreendia a realidade do mundo e de si: o mundo é "sacramental" e o si mesmo é "analogia" com o Mistério. Percebemos esses resultados também na elaboração de experiência presente nas Litterae Indipetae espanholas.

\section{Palavras Chaves}

Educação à Liberdade; Experiência-modelo; Inácio de Loyola; Companhia de Jesus; Correspondência Epistolar - Litterae Indipetae

\begin{abstract}
Based on the concept " experience-model ", we intend to show how the Ancient Society of Jesus (1540-1773) educational project, specifically the aspect called educationto freedom, was basedon Ignatius'slifewhich was offered as a model tobe followed. We are supported by a historiographical study of some Society sources and we used, as a comprehensive model, the proposal that establishes the spiritual-philosophicalinstitutional-rhetorical unit of the Jesuit's experience. We have identified the effectiveness of this pedagogical project in the way the Jesuit apprehended the reality of the world and of himself: the world is "sacramental » and the self is an " analogy »

\footnotetext{
* Doutor em Psicologia pela Universidade de São Paulo; pesquisador da Universidade Federal de Minas Gerais, da Universidade de São Paulo e da Universidade Federal de Ouro Preto, professor da Universidade Presbiteriana Mackenzie São Paulo/SP/Brasil
} 
with the Mystery. We also noticed these results at the experience formulations contained in Spanish Litterae Indipetae.

\section{Keywords}

Education to Freedom; Experience-Model; Ignatius of Loyola; Society of Jesus; Jesuit's epistolary correspondence -Litterae Indipetae

Recibido: 9 de julio de 2013

Evaluado: 15 de julio de 2013 


\section{Premissa}

Tal como é empregado entre os jesuítas, o termo "experiência" deve ser entendido a partir de um complexo feixe de influências: além da assumida posição filosófica aristotélico-tomista, é preciso dizer que parece existir também uma influência agostiniana. E, para além do aspecto puramente filosófico, quando se fala de "experiência” na Companhia de Jesus, se está tratando com uma categoria que também pertence ao universo da regulação tanto espiritual quanto jurídica.

Experientia é pois modo de conhecer, que não se dá simplesmente per modum cogitandi ou somente per modum operandi. A experiência, assim dada a entender, deve ser compreendida como o conhecimento que se adquire após o operari e todas as potências de alma aí envolvidas, e o precedente (e/ou consecutivo) cogitare com suas devidas implicações anímicas. Sabendo-se que o "agir" do homem (conforme essa antropologia filosófica específica sobre a qual nos debruçamos) - seu operar, seu proceder - só se dá na medida em que seja "para conseguir a coisa desejada intencionada" ${ }^{1}$, vê-se uma importante diferença para o que se possa descrever como "ação" contemporaneamente: não se trata do simples movimento verificado apenas externamente - um "comportamento" -, mas da conjugação de uma série longa de fatores, tais como a intencionalidade, que só é colocada em jogo se se considera a vontade e o intelecto, os apetites e as faculdades da alma sensitiva (tanto externas quanto internas). Sabendo-se também que o "cogitar” humano - seu modo de pensar, de inteligir - envolve toda uma gama de faculdades anímicas influenciando umas nas outras... percebe-se que a visão de homem aqui envolvida, quando se fala de experientia é, digamos assim, uma visão totalizante: não há solução de continuidade entre uma e outra operação $^{2}$, trata-se de um contínuo, onde per experientia implica o conhecimento obtido pelo homem total - todos os seus cinco gêneros de potências da alma, suas três almas distintas e seus quatro modos de viver diferentes, e suas devidas implicações ${ }^{3}$.

Falar de espiritualidade nos séculos XVI e XVII, especialmente falar da Devotio moderna, sem dúvida é considerar fatores tais como a retórica, a ética, a política, a teologia etc. Neste caso, espiritualidade, experiência religiosa, mística e fé, são reelaborações ou retomadas de conceitos tomistas, apenas revestidos de roupagens modernas; o que significa uma devoção em nada desvinculada da realidade.

Porém, é Guibert (1953) quem melhor define o que seja espiritualidade, quando explica o que significa uma "espiritualidade inaciana”: segundo ele, o termo designa

\footnotetext{
${ }^{1}$ Aquino, 1947: 166.

${ }^{2}$ Visível e invisível, fato em si e sentido do fato, experiência e fé, corpo e alma, finito e infinito, acidental e fundamental: a mística renascentista com uma definição escolástica, especialmente a dos jesuítas, retoma (ou mantém) a experiência do sagrado como algo do nível dos sentidos, mais que de uma formulação teórica, teológica ou filosófica. Além de acrescentar algo novo: a prática, que tem como representante mais significativo, no caso da então nascente Companhia de Jesus, os Exercícios Espirituais. Massimi (2001:51) afirma, falando da experiência religiosa dos jesuítas: "não há solução de continuidade entre a experiência psicológica e a experiência religiosa, já que ambas são inerentes ao eu do homem. Nem pode haver autonomia entre a esfera psíquica e a esfera espiritual, assim como hoje nós 'modernos' concebemos”. Segundo a tradição da filosofia aristotélico-tomista, conhece-se o fundamental pelo acidental: "conhecemos a alma por seus efeitos, ou seja, por suas funções psicológicas, ou faculdades que se evidenciam no plano dos fenômenos” (Massimi, 2001:53).

${ }^{3}$ Tomás de Aquino é quem assim divide: cinco categorias de potências (vegetativas, sensitivas, apetitivas, motora e intelectivas), três almas (vegetativa, sensitiva e racional) e quatro modos de viver (vegetativo, sensitivo, motivo e intelectivo). Cf. Aquino, 1947: 159-194 (q. LXXVIII).
} 
tanto a vida interior pessoal de um homem, quanto a maneira como esse homem exerce certas práticas genericamente entendidas como espirituais, ou mesmo uma doutrina espiritual presente em escritos desse mesmo homem. No entanto, quando se trata da "espiritualidade" de uma ordem religiosa, por exemplo, na maioria das vezes

cette spiritualité du groupe aura pour point de départ la spiritualité d'un homme, d'un fondateur ou d'un maître, telle qu'elle ressort de sa vie, de ses enseignements et de sa parole, de ses écrits, de tel écrit considéré comme normatif par la tradition vivante du groupe ${ }^{4}$.

Por isso, pela expressão "espiritualidade inaciana”, se quer designar esse conjunto de características próprias da experiência pessoal de Inácio, presente em determinados documentos, que funda um modo próprio de um grupo, no caso a Companhia de Jesus. Descrevamos, suscitamente, duas das fontes mais significativas da Companhia de Jesus: os Exercícios Espirituais e o Relato de Inácio.

Podemos dizer que os Exercícios Espirituais, são - à primeira vista - uma série de notas práticas, de métodos de exame de consciência, de oração, de deliberação ou eleição, de planos de meditação e de contemplação, divididos em partes que indicam quatro semanas, além de regras etc.; um conjunto de instruções diversas destinadas a dirigir o cumprimento de um certo número de exercícios interiores sistematicamente ordenados, de forma que se trata de um livro não para ser lido, mas para ser vivido; mas, sobretudo, trata-se de uma obra destinada a quem guia o exercitante (Guibert, 1953). Quanto à compreensão de como este texto nasceu, qual o seu objetivo e portanto seu lugar na vida de espiritualidade da Companhia de Jesus, é o próprio Inácio quem narra - no seu Relato - como os Exercícios foram escritos: não de uma só vez, "mas, na medida em que observava algumas coisas na sua alma e as achava úteis, e lhe parecia que poderiam ser também úteis aos outros; então as punha por escrito" ${ }^{\text {. }}$. De forma que o texto dos Exercícios Espirituais é produzido como uma experiência pessoal, marcada por acontecimentos que são sinais da presença e da ação de Deus, descrita de maneira a ser útil para que outros homens fossem capazes de trilhar um caminho de experiência de encontro com Deus. O objetivo da obra é suscitar e sustentar uma experiência de eleição da vontade de Deus - "sempre conhecer e cumprir sua divina vontade" -; uma "escola de oração" 6 . Podemos também dizer que os Exercícios são mesmo o ponto de partida fecundo, no sentido de "princípio de orientação e de desenvolvimento de toda esta espiritualidade nascida da experiência de Santo Inácio"7 . E finalmente, segundo O’Malley (1999), "não se pode compreender os jesuítas sem fazer referência” aos Exercícios Espirituais $^{8}$.

\footnotetext{
${ }^{4}$ Guibert, 1953: XVIII.

${ }^{5}$ Loyola, 1991: 1072.

${ }^{6}$ Guibert, 1953: 529.

${ }^{7}$ Ibid.: 537.

${ }^{8}$ Os Exercícios Espirituais demonstram como se dá o conhecimento da realidade: através do transcender a dimensão das operações discursivas e do recorrer à arte da memória e da imaginação. O exercitante é convidado a, fazendo uso da memória, construir uma ponte entre o abstrato de uma afirmação e sua imagem concreta na alma. Essa imagem existe na medida em que quem faz os Exercícios, aprende a usar a potência da imaginação. Podemos dizer ainda que, por "realidade", entende-se tudo que é oposto a ilusório, isto é, o real é tudo o que não está circunscrito às nossas fantasias de onipotência ou de impotência, à ilusão do nosso pecado: não interessam, para Inácio, os limites ou capacidades do homem, interessa que ele se saiba criadopara "louvar e reverenciar” o Criador. É “realidade” também não só o
} 
Quanto ao que concerne ao Relato, o que mais nos interessa é seu caráter "testamentário", que ajuda a entender como a experiência espiritual de Inácio constituiu-se fundamento da Companhia de Jesus. No Relato, a vida de Inácio é mais que uma sequência de acontecimentos: é uma vida marcada, constituída e formada pela graça de Deus; a vida de Inácio se torna, pois, uma "experiência-modelo" (Marin, 1996: $145-146)^{10}$, de forma que ler seu relato significa "reviver a vida do fundador, repetir a vida do fundador como fundador, quer dizer refundar o corpo, reinstituir o instituto que ele fundou a partir de sua conversão" ${ }^{11}$, ou seja, finalmente, é imitar Inácio.

Desse debate, finalmente, pode-se concluir que "experiência” é o contraponto de uma mística do abstrato, onde a experiência de relação com Deus se dá apenas na parte nobre da alma humana - alma racional. Mais uma vez, vemos a afirmação da imprescindibilidade dos sentidos, da experiência sensível. A espiritualidade jesuítica, aqui manifesta especialmente pelo seu texto normativo, reafirma que o conhecimento dedutivo não basta para se chegar a um pleno conhecimento da realidade, ou seja, não basta para chegar a tocar o Sentido, o Bem, a Verdade, o Fim presente, como consistência última, na

mundo visível das pessoas e das “coisas sobre a face da terra”, mas o que há de sentido por trás do visível, o que está para além do visível, que ajuda o homem “a alcançar o fim para que é criado”. Nesse sentido, é "realidade" aquilo para o que somos capazes de lançar um olhar moral, na medida em que aponta ou não o sentido, o fim. Nessa antropologia, o homem é chamado a se relacionar de forma adequada com o real, segundo sua "verdadeira utilidade", e não de forma trivial, reativa ou puramente prazerosa. Para isso, é preciso que a liberdade esteja exercitada na escolha do Bem e Fim últimos, da Verdade. Nos Exercícios, Inácio aponta para a necessidade de "incorporarmo-nos ao real”; real entendido como "incorporado ao ‘desígnio secreto’ de Deus” (Fernández-Martos, 1991: 244) - meta final, sentido último de todo o Universo. Mas, com que recursos o homem pode identificar na realidade essa meta final apenas sinalizada? Aqui, podemos apresentar a preocupação de Inácio com a “aplicação dos sentidos”. Para ele, a consistência última da realidade é apreendida pelos sentidos - ver, tocar, ouvir, degustar, sentir o cheiro -, e não por um exercícios de abstração metafísica. Essa aplicação - intuitiva a princípio e cada vez mais possível na medida em que se simplificam as faculdades espirituais, exercitando-as - ajuda a recolher os frutos da meditação de todo um dia: localizados na experiência sensível, estes frutos são melhor percebidos como pessoais e, portanto, melhor julgados pela razão.

${ }^{9}$ Nadal, no prefácio ao Relato diz que o pedido feito a Inácio foi de relatar sua vida "desde o início de sua conversão”, com o objetivo de "servir para nós como um testamento e um ensinamento".

${ }^{10}$ Com respeito ao Relato de Inácio, Marin que denomina o texto de "autobiofonia”, explica que se trata de um documento no qual Inácio é dado ao leitor como um “imitável, um modelo” (Marin, 1996: 140). Este texto permite "reviver a vida do fundador, repetir a vida do fundador” (Marin, 1996: 146), que é mais do que uma série de eventos, mas o tecido dos eventos ("tudo o que se passou em sua alma até o dia de hoje”) dirigidos pelo Senhor "desde a sua conversão": "Mas se o próprio de um modelo é de ser imitável, portanto reiterável e repetível, como repetir uma vida dirigida e formada pelo Senhor? Como repetir as intervenções divinas que (...) constituem a vida do fundador, o legendum singular desta vida? Como fazer da leitura do relato desta vida, um modo de repetição desta vida mesmo depois de seu verdadeiro nascimento até o momento onde ela termina? (...) Trata-se, em uma palavra, de escrever 'o relato’ no corpo segundo uma modalidade encarnada de sua leitura, ou (...) descobrir a maneira na qual cada companheiro leitor se apropria singularmente, segundo sua vocação, da experiência do fundador” (Marin, 1996: 147). Ler o Relato, portanto, tem, segundo Marin (1996), dignidade sacramental, na medida que pode ser descrito como uma espécie de comunhão eucarística, na medida em que o texto se torna corpo em quem lê: é a experiência pessoal de Inácio que é dada como paradigma de identificação e incorporação (dois termos que não nos são mais estranhos). O paradoxo apontado pela pergunta de Marin (1996) - o de ser a vida de Inácio dada à imitação apesar de ter sido uma vida formada e dirigida por Deus - se desfaz na interseção entre Graça Divina e Vontade Humana, que nessa visão de homem é tão presente: a experiência da Graça Divina na vida de Inácio, faz dele um modelo, um imitável, um texto vivo para seus companheiros, que, no entanto, têm a liberdade de colocar em operação sua Vontade pessoal para encarnar em suas vidas (ou não) essa “experiência-modelo” (Marin, 1996).

${ }^{11}$ Marin, 1996: 147.

71 Paulo Roberto de Andrada Pacheco. Inácio de Loyola ... 67-91 
realidade: é preciso a experiência imediata, é preciso o conhecimento direto proporcionado pelos sentidos e pela consciência de si mesmo, é preciso a experiência das coisas percebidas, que são conhecidas na medida em que as vivemos, as tocamos, ouvimos, experimentamos... "sentir y gustar de las cosas internamente"12.

\section{Liberdade: Razão e Adesão}

Na terça-feira dia 26 de fevereiro de 1544, em seu Diário de Moções Espirituais $^{13}$, Inácio relata estar "mais satisfeito e mais contente de deixar-me governar pela divina Majestade" ${ }^{14}$. O que ele quer dizer com isso?

Se entendemos que essa, assim chamada, moção espiritual ou interior é o "movimento ou inclinação da vontade pela graça de Deus, que não suprime a liberdade humana, mas a move pelo bem que lhe mostra"15, fica claro que tal "deixar-se governar” está estreitamente vinculado à realização da pessoa, tanto é verdade que o próprio Inácio, dias mais tarde, afirma: "Seguindo-vos, meu Senhor, eu não poderei me perder" ${ }^{\prime 6}$. Esta alegria é, pois, a alegria de encontrar e ver realizada sua próprio humanidade. Mas, fica ainda uma pergunta: em que sentido "buscar a vontade de Deus em toda a sua perfeição e beneplácito" 17 ou não afirmar nada "de nossa própria cabeça e entendimento, mas só o que o Senhor nos inspirar"18 é capaz de realizar a humanidade de uma pessoa? Ou, em outras palavras: em que sentido, obedecendo me torno livre realmente, ou seja, realizado?

Lembremo-nos que o caminho proposto por Inácio - em tudo coerente com a

\footnotetext{
${ }^{12}$ García-Mateo, 1998: 478-479.

${ }^{13} \mathrm{O}$ aspecto mais revelador deste maço de folhas autógrafas a que se deu o nome de Diário, é justamente o fato de que se tratam de notas advindas de uma elaboração da experiência pessoal. Assim, a própria linguagem utilizada no texto se torna objeto da nossa atenção. Não é, pois, de se estranhar que os trechos que se seguem às vezes sejam impessoais, ou se caracterizem por uma simples descrição de um estado emocional, ou de uma consideração feita, ou de um sentimento provado etc. Por exemplo, no dia 4 de fevereiro de 1544, uma segunda-feira, Inácio escrevia: "Mesma coisa [referindo-se ao que havia escrito no dia anterior: "abundância de devoção na missa, lágrimas, grande confiança em Nossa Senhora" (Loyola, 1991: 327)], e também outros sentimentos” (Loyola, 1991: 327), sendo que quando ele faz uso do termo "sentimentos", não só aqui mas ao longo de todo o Diário, não está prescindindo de uma compreensão intelectual: sentir, em espanhol, é indissociável do intelecto, do afeto e da sensibilidade envolvidos. E isso se pode comprovar, por exemplo, quando o vemos escrever, alguns dias mais tarde que "depois do despertar, eu não parava de render graças a Deus nosso Senhor muito intensamente, com inteligência e lágrimas, por um tão grande bem e uma tão grande luz recebida, que não podem ser expressas” (Loyola, 1991: 331-332). Ou mesmo quando faz uso de jogos de palavras tais como "inteligência espiritual", "sentindo o Filho muito propício para interceder", "vendo os santos de uma tal maneira que não se pode escrever" (Loyola, 1991: 333), ou "tão grandes inteligências que não se pode escrever" (Loyola, 1991: 334), ou ainda "esse sentimento ou essa visão", "sentindo muitas inteligências importantes, saborosas e muito espirituais” (Loyola, 1991: 335) e, para não estender por demais esta lista, mesmo quando relata que "um conhecimento me veio de que um tal pensamento era também de Deus" (Loyola, 1991: 337), ou que provou "certo sentimento ou visão pelo entendimento" (Loyola, 1991: 342) etc.

${ }^{14}$ Loyola, 1991: 344.

${ }^{15}$ Cardoso, 1977: 19.

${ }^{16}$ Loyola, 1991: 350.

${ }^{17}$ Loyola, 1977: 86.

${ }^{18}$ Ibid.: 88.
}

72 Paulo Roberto de Andrada Pacheco. Inácio de Loyola ... 67-91 
tradição aristotélico-tomista da Segunda Escolástica dos séculos XVI e XVII - é um caminho que leva à "liberdade real” (Fernández-Martos, 1991): deixando-se governar pela Graça Divina, obedecendo à Sua Vontade, adere-se ao Ser, participa-se dEle como "um só espírito", deixa-se causar livremente por Aquele que é a consistência última e inexorável da humanidade e do homem individual.

A tópica da "eleição por conformidade" ou da "obediência” se esclarece neste horizonte apenas esboçado. Para dar forma mais clara a este horizonte, será preciso considerar uma outra tópica comum dos anos quinhetos e seiscentos ibéricos: o "desengano" ou "desconcerto do mundo". Trata-se daquele lugar comum que buscava descrever a inconsistência de per se da realidade: a brevidade da vida, a efemeridade da existência e da passagem do tempo. Tema já presente, por exemplo, no chamado de atenção do apóstolo Paulo, na carta enviada aos cristãos de Corinto: "passa a figura deste mundo"19, ou seja, toda a realidade corre para o nada, as coisas todas são instáveis, fugazes, mutáveis. Se as coisas do mundo são assim inconsistentes, o sentido do tempo é cuidar do que é consistente, imutável, estável, eterno: temporal X eterno; onde o temporal só tem valor se usado em função dos bens eternos.

O "desengano" - este trabalho pessoal de fugir do engano a que se é induzido pela aparência do mundo - coincide exatamente com este juízo acerca do uso do temporal:

não corresponde apenas a um sentimento psicológico da vida, mas sugere uma modalidade de uso das coisas e dos relacionamentos na consciência de sua paradoxal dimensão passageira e definitiva. Em suma o significado temporal de cada coisa e pessoa só pode ser adequadamente afirmado na consideração de seu sentido último ${ }^{20}$.

Trata-se, portanto, de um verdadeiro conhecimento da realidade, onde o indivíduo é chamado a apreender o sentido das coisas, pessoas e fatos presente, ainda que velado pelas aparências, imagens, "figuras" do mundo.

Se o temporal é enganador, a atitude razoável, a atitude adequada à ordo na qual ratioe natura humana se realizam perfeitamente, é aquela da subordinação à Verdade Eterna, ou de uma escolha conformada à Providência Divina: obediência, portanto ${ }^{21}$.

Pécora (1998) explica que a Providência, segundo o pregador jesuíta Padre

\footnotetext{
${ }^{19} 1$ Cor 7,29.

${ }^{20}$ Massimi, 2001: 23.

${ }^{21}$ Pécora (1998), tratando dos sermões fúnebres do Padre Antônio Vieira, descreve o que o pregador jesuíta diz em seu sermão das exéquias de D. Maria: "Danslesecondemoitiédusermon, élaboréecomme une réfutation de la première, Vieira fait parlerla Providence pourmieuxrépondreauxplaintesantérieurementformuléescontreelle. Ainsi, en ce qui concerne la morte prématurée, le jésuite n’y voit aucune négligence, mais, au contraire, une concession de grâce faite à $\mathrm{D}$. Maria afin d' 'éterniser son âge'. Il existe donc une préoccupation divine pour que, en perdant des jours en ce monde, elle puisse 'les multiplier' dans la vie éternelle des bienheureux. Il réfute, de même, la plainte motivée par la perte de la beauté: D. Maria n’a fait que troquer une beauté mineure pour une plus grande, celle du corps contre celle de l'esprit. En associant l'argument aux lieux de détrompement et vanitas, Vieira remarque encore que, outre l'avantage de cet échange d'une beauté physique pour une beauté spirituelle, la mort précoce l'a sauvée de l'inexorable ruine de cette beauté au long des années. Pour finir, la 'discrétion', n'aurait pas non plus de raison de se plaindre puisque la plus grande discrétion consiste en 'savoir mourir' et non pas en 'savoir dire'. La mort seule permet de distinguer le discret véritable: ce n'est qu’au moment des choix définitifs qu’on en observe la réussite ou l’erreur” (pp. 194-195).
} 
Antônio Vieira, é uma “disposição ordenada dos decretos divinos”, assim “ela pode se conciliar perfeitamente com a escolha humana, em virtude da 'conformidade', quer dizer, em virtude de nossa capacidade de nos conformarmos voluntariamente às ordens de Deus" ${ }^{22}$. De maneira que, "pela obediência, participamos da Providência" ${ }^{23}$ : através da obediência, o ato humano se conforma à vontade de Deus, sendo, portanto, a obediência de conformidade mais perfeita que a obediência de deliberação, porque pela conformidade, o ato além de humano é divino:

On remarque, en premier lieu, que le providentiel, dont la mort serait l'outil privilégié, ne se soucie ni du mondain ni du passager, mais seulement du spirituel et de l'éternel. On en tire la conclusion, jésuitique par excellence, que se conformer à la Providence, sans révolte, fait de celle-ci un véritable bien de l'homme. Ce qui veut dire qu'en acceptant la mort, on atteint la véritable réalité de ce qu'elle semblait nier: la vie bienheureuse de laquelle jeunesse, beauté et intelligencen'étaient que faux-semblants ${ }^{24}$.

Percebe-se que, aqui, a pergunta que está por trás desta dinâmica que o homem vive diante da aparência do mundo e da Providência, diante da sorte e da morte em oposição à eternidade, é a pergunta que o salmista faz: "quando vejo o céu, obra dos teus dedos, a lua e as estrelas que fixastes, que é o homem para dele te lembrares, e o filho do homem para que o visites?" ${ }^{25}$. De fato, diante da "presença divina oculta no visível do mundo" ${ }^{26}$, a experiência da auto-consciência pode não ser óbvia e imediata, mas é, mediada pela Igreja, uma experiência possível, direta, individual e extática. E a experiência-modelo de Inácio parece responder àquela pergunta, como escreve o P.e Câmara no Relato do Santo, quando diz que

a maior consolação que recebia era olhar o céu e as estrelas, o que ele fazia frequentemente e durante um bom espaço de tempo, porque com isto ele sentia em si um muito grande esforço para servir nosso Senhor ${ }^{27}$.

O que Inácio entende por esta ação muito específica - "servir a Nosso Senhor”? Não se trata de um puro ato voluntarista, sem objetivo ou finalidade, mas o dinamismo vital de fazer a vontade de Deus, num movimento ascensional em direção a Ele, e impulsionado por Ele mesmo. Mas, onde está o lugar da liberdade nessa ação aparentemente "escrava” da Graça Divina? Para falarmos disso, é preciso trazer à baila as categorias de consolação e desolação: corolários de um tal "agir” ou "não agir”.

Inácio, nas Regras para sentir e reconhecer de algum modo as diversas moções que se produzem na alma, as boas para as receber e as más para as rejeitar, explica que consolação é aquele inflamar da alma "no amor do seu Criador e Senhor; e não poder mais amar coisa alguma criada sobre a face da terra por si, mas somente no Criador de todas essas coisas”28. Desolação, por sua vez, é exatamente o movimento contrário, de afastamento do Amor e da Vontade de Deus, portanto.

\footnotetext{
${ }^{22}$ Pécora, 1998: 195.

${ }^{23}$ Ibid.: 195.

${ }^{24}$ Ibid.: 196.

${ }^{25} \mathrm{Sl} 8,3-4$.

${ }^{26}$ Pécora, 1999: 99.

${ }^{27}$ Loyola, 1991: 1023.

${ }^{28}$ EE. 316; Loyola, 1991: 224.
} 
Segundo Inácio, nas mesmas regras, a desolação tem sua fonte em Satanás - o "Inimigo da natureza humana" - que procura impedir nossa liberdade de aderir ao Sumo e Verdadeiro Bem. É aqui, justamente, onde entra a resposta àquela pergunta - onde está o homem entendido como ontologicamente livre nessa aparente "ação escrava”?

Inácio nos lembra que, mesmo sendo obra do "Inimigo da natureza humana", devemos nos servir da desolação - com a ajuda da graça -, bem como de todo o sofrimento, para progredir e nos abrir mais à ação de Deus e à consolação que Ele promete àqueles que fazem Sua Vontade. Nessa iniciativa do homem - que passa basicamente pelo tripé oração-exame-penitência - o homem age não mais como "escravo"; porque então se trata de uma iniciativa que nasce do juízo acerca da própria experiência, onde "usamos dos atos da inteligência, quando refletimos e dos da vontade, quando experimentamos sentimentos" ${ }^{29}$ : é o homem todo que é solicitado nessa iniciativa, é o homem internamente ordenado.

Isso fica ainda mais claro se nos remetemos ao título dos ExercíciosEspirituais Exercícios Espirituais para se vencer a si mesmo e ordenar sua vida sem se determinar por nenhuma afeição desordenada -, que aponta para a sua intencionalidade última: o restabelecimento da ordem interna do homem, o retorno à consciência do bem real a que todo homem deseja, a partir da supressão de todo o apego aos bens aparentes que dificulta a livre atividade de suas forças e as impedem de se submeter à Vontade Divina. Nesse sentido, os ExercíciosEspirituais são um método para encontrar a Deus que se revela, uma possibilidade concreta na qual o homem, libertado pela Graça de Cristo, aprende a aderir, por uma escolha cada vez mais lúcida, esclarecida e livre, à ação do Espírito Santo.

Desse modo, se o homem considera o fim para que foi criado, se se torna indiferente, se afasta as afeições desordenadas, é então capaz de escolher aquilo que é ad maiorem Dei gloriam:

É preciso ter por objetivo o fim para que fui criado: louvar a Deus nosso Senhor e salvar minha alma; além disso, eu devo me encontrar indiferente, sem nenhuma afeição desordenada, de tal maneira que eu não seja mais inclinado ou afeiçoado a me prender à coisa visada que a perdê-la, nem mais a deixá-la que a mantê-la. Mas que eu me atenha ao meio, como numa balança, para seguir aquilo que eu sentirei ser mais para a glória e o louvor de Deus nosso Senhor e salvação de minha alma ${ }^{30}$.

Inácio faz uso da categoria da "indiferença" para designar esse passo de diferenciação entre o homem e a realidade (Fernández-Martos, 1991). Caberá à indiferença permitir ao homem, na distância, vislumbrar o verdadeiro sentido do real, de modo que se possa melhor inteligir o que o circunda.

Assim entendida e descrita, a indiferença se torna fator fundamental para uma experiência de liberdade. Sem a indiferença, parece impossível o perfeito uso das faculdades da alma, o que torna remoto todo sentido, pensamento e oração. No entanto, é preciso ter claro que o homem é uma dinâmica de emersão e imersão da e na realidade, de forma que a experiência definitiva de liberdade é ainda e somente promessa evangélica: a perfeição e a consolação eterna são prometidas àqueles que

\footnotetext{
${ }^{29}$ EE. 3; Loyola, 1991: 48.

${ }^{30}$ EE. 179; Loyola, 1991: 144.
} 
forem radicalmente fiéis a Deus e o seguirem, esvaziando-se de si mesmos, e se dispuserem a realizar Sua Vontade. Por isso, já no início dos ExercíciosEspirituais, Inácio lembra que

Muito se aproveita ao exercitante entrar neles com um coração largo e grande generosidade para com seu Criador e Senhor, oferecendo-lhe todo o seu querer e toda a sua liberdade, para que sua divina Majestade se sirva de sua pessoa bem como de tudo o que possui, conforme a sua santíssima vontade $^{31}$.

Mais à frente, na Contemplação para Alcançar o Amor, Inácio insiste na oferta da própria vida como pedido para ser disponível à Vontade de Deus:

Tomai, Senhor, e recebei toda minha liberdade, minha memória, minha inteligência e toda minha vontade; tudo o que tenho e tudo o que possuo; Vós me destes; a vós, Senhor, o restituo. Tudo é vosso, de tudo disponde segundo a vossa inteira vontade. Permiti-me vos amar, dai-me a vossa graça, que isso me basta ${ }^{32}$.

Outro aspecto importante para ser considerado na análise dos ExercíciosEspirituais é o que se refere à proposta da Primeira Semana: a meditação dos pecados e de suas consequências. A dinâmica sugerida passa pela meditação do pecado dos anjos, do pecado de Adão e Eva e, finalmente, dos pecados particulares dos homens.

Olhando para o próprio pecado e limitação, o homem é capaz de reconhecer-se participante de uma mesma dinâmica universal - a da queda. Além disso, meditando o amor de Cristo que pagou o preço do resgate do seu pecado, se entregando à morte de Cruz, para recolocá-la na sua posição original, para fazer emergir sua humanidade verdadeira ("imagem e semelhança"), o homem então, partindo da justa pergunta "o que fiz por Cristo, o que faço por Cristo e o que devo fazer por Cristo?" 33 , é capaz de um compromisso apostólico e missionário com a realidade baseado na eleição e oblação que nasce de uma identificação com Cristo.

E é justamente essa identificação o objetivo da Segunda Semana: onde Inácio propõe "amar e seguir mais” a Cristo (cf. EE. 104), imitá-Lo (cf. EE. 98), "assemelharse a Ele mais efetivamente" (cf. EE. 167), servi-Lo (cf. EE. 168), participar de Seus sentimentos (cf. EE. 203), ter um "conhecimento interior do Senhor” (cf. EE. 104), visando, com fórmulas como essas, dar instrumentos para quem faz os Exercícios Espirituais que permitam a união da sua vontade à Vontade de Deus (cf. EE. 180): o termo e o meio do verdadeiro amor.

Assim, tendo reconhecido o pecado, a queda da posição original, surge no homem o desejo de um novo nascimento, de uma mudança radical, de uma conversão. Esse nascimento implica também que se identifique um novo modelo para a imitação. Mas qual? Com quem? Como localizar esse "alguém” com quem se identificar para o novo nascimento?

Nesse ponto, a experiência-modelo de Inácio ajuda o "exercitante” a dar passos significativos no rumo de uma resposta. Começa, ajudando a localizar na realidade, na

\footnotetext{
${ }^{31}$ EE. 5; Loyola, 1991: 50.

${ }^{32}$ EE. 234; Loyola, 1991: 172.

${ }^{33}$ EE. 53; Loyola, 1991: 84.
} 
experiência pessoal, uma presença com quem se viva um relacionamento de identificação: alguém a quem se sirva cotidianamente. Por isso, na primeira parte desta semana, Inácio propõe meditar o serviço a um rei cristão, humano e temporal, o que era próprio dos homens de sua época. Já na segunda parte, a proposta é que se medite o serviço a Cristo, o Rei eterno, Aquele que diz ao homem:

Minha vontade é conquistar o mundo inteiro e todos os inimigos e assim entrar na glória de meu Pai; consequentemente quem quiser vir comigo deve penar comigo, a fim de que, seguindo-me nas penas, siga-me também na glória $^{34}$.

O fundador da Companhia de Jesus quer imergir o homem na pessoa de Cristo (depois de o ter feito emergir da realidade), para que, seduzidos pela "suavidade e doçura infinitas da divindade" 35 , se torne óbvio no homem a rapidez e diligência "para cumprir sua santíssima vontade" ${ }^{\text {36 }}$. Imergir na pessoa de Cristo é, finalmente, tê-Lo como modelo de imitação.

É a identificação que permite que um homem se converta em um outro, passando a sentir e se comportar do mesmo modo que o segundo: olha-se para a realidade, vive-se na realidade como esse outro - mais perfeito e realizado. Daí, se se passa a desejar mais a pobreza, as injúrias, ou a estima de ignorante e louco, é porque já se iniciou definitiva e irremediavelmente o processo de identificação com Cristo, que é pobre de riquezas, cheio de injúrias e que primeiro foi tratado como ignorante e louco (cf. EE. 167).

Assim, a determinação de realizar "sua santíssima vontade" não é mais fruto de uma "vontade hercúlea" ou de uma capacidade especial de uns poucos, mas é tão somente fruto da percepção do que é, em última instância, a nossa realidade limitada.

Ainda na Segunda Semana, no Preâmbulo para Fazer Eleição, Inácio retoma os termos do Princípio e Fundamento ${ }^{37}$ para nos lembrar qual é o verdadeiro objetivo da vida do homem:

Em toda boa eleição, na medida em que isso dependa de nós, o olho de nossa intenção deve ser simples, olhando unicamente aquilo para que fui criado: para o louvor de Deus nosso Senhor e a salvação de minha alma. (...) Porque nós devemos nos propor em primeiro lugar, como objetivo, querer servir a Deus, que é o fim ${ }^{38}$.

\footnotetext{
${ }^{34}$ EE. 95; Loyola, 1991: 104.

${ }^{35}$ EE. 124; Loyola, 1991: 116.

${ }^{36}$ EE. 91; Loyola, 1991: 102.

37 "O homem é criado para louvar, reverenciar e servir a Deus Nosso Senhor, e assim salvar a sua alma. E as outras coisas sobre a face da terra são criadas para o homem, para que o ajudem aalcançar o fim para que é criado. Donde se segue que há de usar delas tanto quanto o ajudem a atingir o seu fim, e há de privar-se delas tanto quanto dele o afastem. Pelo que é necessário tornar-nos indiferentes a respeito de todas as coisas criadas em tudo aquilo que depende da escolha do nosso livre-arbítrio, e não lhe é proibido. De tal maneira que, de nossa parte, não queiramos mais saúde que doença, riqueza que pobreza, honra que desonra, vida longa que breve, e assim por diante em tudo o mais, desejando e escolhendo apenas o que mais nos conduz ao fim para que fomos criados” (EE. 23; Loyola, 1991: 62-64, grifos nossos).

${ }^{38}$ EE. 169; Loyola, 1991: 137.
} 
Uma atitude iluminada pela razão e deliberada pela vontade é aquela dirigida a um fim. Mas, o que é razão ${ }^{39}$, conforme a entende Inácio e, especialmente, como aparece nos ExercíciosEspirituais? Trata-se de uma faculdade espiritual que participa do dinamismo que nos impele a agir na direção do Bem. Não é exatamente a sensibilidade (sensualidad) e deve-se distinguir também do entendimento, faculdade discursiva, que de si mesma não indica nenhum impulso para o Sumo Bem. Um exemplo do uso da razão aparece nos Exercícios 97 e 98, quando Inácio diz:

Os que quiserem mais se ligar e se distinguir em todo serviço junto de seu rei eterno e Senhor universal, não somente oferecerão suas pessoas à pena, mas ainda, agindo contra sua própria sensualidade e contra seu amor carnal e mundano, farão oferta de maior valor e maior importância, dizendo: "Eterno Senhor de todas as coisas, faço a minha oferta, com vosso favor e vossa ajuda, em presença de vossa infinita bondade e em presença de vossa mãe gloriosa e de todos os santos e santas da corte celeste: quero e desejo, e é minha decisão determinada, contanto que seja vosso maior serviço e vosso maior louvor, vos imitar suportando todos os ultrajes, todas as humilhações e toda pobreza, seja efetiva que espiritual, se vossa santíssima Majestade me quiser escolher e receber nessa vida e nesse estado" ${ }^{40}$.

Ou seja, são as faculdades da alma racional - razão e vontade agindo juntas -, ou melhor dizendo, é a “decisão deliberada” ou a "liberdade” (entendidas em estreita relação com a razão, como vimos na análise dos textos do scholicorum) as responsáveis por, no olhar para a realidade, tendo identificado o Bem e o Fim últimos da vida, deliberar em favor de sua aplicação para cumprir esse objetivo final. Literalmente, a razão dá - ou localiza, ou ilumina - as razões da ação humana.

Esses documentos são, pois, fontes que nos permitem conhecer, por um lado, os fundamentos teológicos da doutrina da Companhia - em geral - e por outro lado a fundação da sua espiritualidade - em particular -, na medida em que são instrumentos que servem à ordenação da vida espiritual dos jesuítas. Podemos então dizer que se trata de documentos prescritivos de uma "ação" com características genericamente entendidas como "espirituais". A liberdade aqui dada a entender é uma adesão à vontade de Deus: livre de sua vontade pessoal, livre das paixões desordenadas, o homem vai, aos poucos, se identificando com Cristo que obedecia ao Pai.

\footnotetext{
${ }^{39}$ Pécora (1999) lembra que, para um jesuíta, razão é sempre entendida do ponto de vista tomista, ou seja, é "sempre 'razão natural', isto é, potência humana que participa da lexnaturalis que Deus inscreve em todo o criado e cujo funcionamento, por ter tal Causa, tende a tal Fim" (p. 145). Uma ponte com o "desengano" e com a "obediência” (e, portanto, nada paradoxalmente, com a "liberdade”): “O ‘engano do mundo’ é um lugar-comum do XVI e XVII - mas é preciso notar que, numa perspectiva cristã, esse engano se refere não à atribuição maniqueísta do mal ao mundo e a recusa do sensível ou da matéria, que, para os tomistas (...), participa da essência mesma do homem. O 'engano' refere-se sempre à ilusão de perpetuidade ou de autonomia substancial daquilo que apenas é ou significa na relação participada do divino. Atribuir eternidade ao temporal, estabilidade ao provisório, descuidando de que o ser, na contingência, é sobretudo analogia, eis aí a essência do engano barroco. Propõe-se, assim, a retomada do tema da vanitas (Eclesiastes 1,2), e a contrapartida dele é o desengano, sobretudo promovido pelo tempo que torna escarmentado o sujeito de suas fantasias de autonomia e independência” (Pécora, 1991: 160).
}

${ }^{40}$ EE. 97-98; Loyola, 1991: 106. 


\section{Educar ao conhecimento de si}

Massimi e Prudente (2002), afirmam que o termo "desejo" é comum à forma mentis do jesuíta ${ }^{41}$ que encontra, por exemplo, nos Exercícios Espirituais o estabelecimento de um protocolo de ordenação do desejo; ou no Relato de Santo Inácio a experiência-modelo de um desejo que saiu da desordem (desejos mundanos ${ }^{42}$ ) para chegar à ordem (desejo de imitar os santos ${ }^{43}$, desejo de ser útil ${ }^{44}$ ) por meio da graça de Deus e do trabalho ascético; ou no Diário de Moções Interiores, onde o termo aparece de novo como experiência de aplicação dos instrumentos ordenadores com o intuito de se fazer uma eleição mais adequada à glória de Deus e ao fim da Companhia; ou mesmo nas Constituições, nas quais encontramos o "desejo" descrito, por exemplo, como um dos pontos a serem examinados no momento da entrada na Ordem ${ }^{45}$, ou como aquilo que faz do jesuíta um jesuíta de fato ${ }^{46}$.

\footnotetext{
${ }^{41}$ Mas não apenas do jesuíta: Certeau (1982) lembra como esta é uma constante no discurso espiritual dos séculos XVI e XVII. Pécora (1994) também lembra que "desejo" é um termo típicamente "humanista" e neo platônico, que, na tradição da segunda escolástica, assume um duplo valor: por um lado positivo (designado, na maior parte das vezes, pelo termo "vontade") e, por outro lado negativo (quando associado aos termos "apetite" ou "paixão"). Desejo, nesse contexto, é "ponte ascensional para Deus, com a generalidade propriamente humana que define: o desejo é natural do homem. Enquanto um dado da natureza, de sua lei e ordem, não pode constituir em si, de uma perspectiva cristã ortodoxa, um 'erro'. O desejo tão-somente anuncia uma ausência graduada do que é da ordem do Ser, uma falta real, portanto, mas nunca absoluta, após a queda. Para supri-la adequadamente, é necessário preenchê-la com uma qualidade da substância análoga ao Ser único de Deus (...): uma qualidade substancial que se desenvolve e aprimora na medida em que a criatura humana molda a existência por uma legítima vontade de assemelhar-se ao que é da ordem divina" (Pécora, 1994: 117).

${ }^{42}$ No início do Relato, P.eLuis Gonçalves da Câmara conta como "Até os 26 anos de vida, ele foi um homem dado às vaidades do mundo; ele se deleitava sobretudo no exercício das armas, com um grande e vão desejo de ganhar honra” (Loyola, 1991: 1019). Mais à frente: "em seguida, outras coisas aconteciam, às quais sucediam os pensamentos do mundo (...), e ele parava também nesses pensamentos por largos momentos e esta sucessão de pensamentos tão diversos durava para ele muito tempo, e ele permanecia sempre no pensamento que se lhe apresentava, quer se tratasse de explorações do mundo que ele desejava fazer ou de outras explorações para Deus que se ofereciam à sua imaginação” (Ibid.: 1021-1022).

${ }^{43}$ O Relato conta que "os desejos de imitar os santos se apresentavam a ele, e ele considerava menos as circunstâncias que o fato de se prometer, assim, com a graça de Deus, fazer como eles tinham feito" (Ibid.: 1022).

${ }^{44}$ Assim aparece no Relato: "ora, no tempo de sua prisão em Salamanca, os mesmos desejos não lhe faltavam de ser útil às almas e, para isso, estudar primeiro, reunir alguns homens que tivessem o mesmo desígnio e guardar aqueles que ele tinha” (Ibid.: 1055). Ou então, o que aconteceu mais tarde, quando já estando em Paris, soube de um amigo que havia ficado doente em Rouen e se decidiu ir em sua ajuda: "e o desejo lhe veio de ir visitá-lo e ajudá-lo. Ele pensava também que, nessa conjuntura, poderia lhe vencer com a ideia de deixar o mundo e se consagrar inteiramente a serviço de Deus. Para poder obter esse resultado, veio-lhe o desejo de fazer as 28 milhas que separam Paris de Rouen a pé descalço, e sem comer ou beber" (Ibid.: 1059).
}

${ }^{45}$ Assim diz a letra da regra: "É preciso igualmente fazer observar àqueles que se examina, e a isso dar muita importância e preço alto diante de nosso Criador e Senhor, o quanto é uma ajuda e um proveito para a vida espiritual ter em horror, totalmente e não em parte, tudo o que o mundo ama e abraça, e aceitar e desejar com todas as suas forças tudo o que Cristo nosso Senhor amou e abraçou" (Const. §101; Loyola, 1991: 416).

${ }^{46}$ Massimi e Prudente (2002) assinalam como no texto das Constituições, o termo desejo aparece ligado a objetos que definem finalmente o que seja o jesuíta. Os desejos têm como objeto "a maior glória de Deus" (Const. §§ 156, 269, 602), "o serviço divino" (Const. § 33), "o bem maior e universal da Companhia" (Const. § 259), “a conversão espiritual”, "a santificação e a perfeição interior”, "o aumento das virtudes” (Const. § 484), “a observância das Constituições da Companhia” (Const. § 602) etc. “Ajuda-se o próximo por desejos apresentados a Deus nosso Senhor e por orações a toda a Igreja, especialmente por aqueles 
Seja como for, nessa perspectiva particular em que aparece o termo "desejo", interessa muito que se saiba se é ordenado ou se é desordenado, se é uma inspiração vinda de Deus, ou se é fruto de uma tentação do Inimigo da natureza humana... Um desejo desordenado é um desejo que não é teleologicamente orientado, entendendo-se esse fim a que se orienta como "o Fim", ou seja, "a honra e glória de Deus nosso Senhor" e a "salvação espiritual das almas" 47 .

O desejo ordenado é, portanto, aquele que se conforma à Vontade de Deus até o ponto da identificação entre o exercitante e o Cristo, de quem ele mais se aproxima e se une na medida em que afasta o espírito das muitas coisas do mundo e se aplica totalmente a apenas uma coisa: "o serviço de seu Criador e o proveito de sua alma", usando "mais livremente suas faculdades naturais para buscar com cuidado aquilo que tanto deseja"48. E, o que o homem "tanto deseja", é "louvar, reverenciar e servir a Deus nosso Senhor e por meio disso salvar sua alma"49, como o afirma o Princípio e Fundamento, ao descrever a verdadeira vocação do homem.

E quanto a este termo, encontramos um sem-número de referências a ele nos mais diversos textos da Companhia de Jesus. A primeira vez em que aparece é em um dos Documentos de Fundação, quando, relatando a maneira como se instituiu a Ordem, se diz:

estávamos divididos em pareceres e opiniões que divergiam com relação ao nosso estatuto, e tínhamos um só e mesmo pensamento e vontade, que era buscar “o bom prazer e a perfeita vontade de Deus”, segundo a visada de nossa vocação ${ }^{50}$.

E qual é essa “nossa vocação”? ?11 A “honra e a glória” de Deus e a “salvação das

que, 'nela, nem mais importância para o bem comum', assim como pelos amigos e benfeitores vivos e mortos, quer eles tenham pedido ou não estas orações; far-se-á essas orações também por aqueles a quem eles venham particularmente em ajuda e aos outros membros da Companhia nos diversos países, entre os fiéis e os infiéis, a fim de que Deus disponha a todos a receber sua graça, através dos frágeis instrumentos desta tão pequena Companhia” (Const. §638; Loyola, 1991: 555).

47 "Para que o Criador e Senhor aja mais seguramente em sua criatura, se acontecer que esta alma esteja presa e inclinada a uma coisa de maneira desordenada, lhe convém reagir com todas as suas forças (...). Assim, por exemplo, se ela está presa à busca e posse de um cargo ou um benefício não pela honra e glória de Deus nosso Senhor nem pela salvação espiritual das almas, mas por uma sua vantagem pessoal e por seus interesses temporais, ela deve se ligar ao oposto, insistindo bastante nas suas orações e outros exercícios espirituais, e pedindo o contrário a Deus nosso Senhor; quer dizer, que ela não quer este cargo, este benefício nem nenhuma outra coisa, a menos que sua divina majestade, ordenando seus desejos, não mude nela seu primeiro vínculo; de tal maneira que o motivo para desejar ou possuir tal ou tal coisa seja unicamente o serviço, a honra e a glória de sua divina majestade” (EE. 16; Loyola, 1991: 56).

${ }^{48}$ EE. 20; Loyola, 1991: 62.

${ }^{49}$ EE. 23; Loyola, 1991: 62.

${ }^{50}$ Loyola, 1991: 277.

${ }^{51}$ Em carta enviada aos Padres e Irmãos de Coimbra, aos 07 de maio de 1547, Inácio escreve: “Considerai o que é vossa vocação, vereis que aquilo que entre os outros não seria pouca coisa, sê-lo-ia no entanto para vós. Não somente Deus vos chamou das trevas à sua admirável luz e vos transportou ao reino de seu Filho bem-amado, mas também o fez para todos os fiéis, para que vós conserveis intacta a pureza de vossa intenção e para que tenhais um amor muito forte nas coisas espirituais que são de seu serviço, ele quis vos arrancar do mar perigoso do mundo, por medo que vossa consciência estivesse em perigo em meio às tempestades que levantam seja o vento do desejo das riquezas, honras ou prazeres, seja, pelo contrário, o vento que faz temer os perder. Ainda mais, para que vosso espírito ou vosso amor não fossem pegos por esses baixos interesses (...), ele quis que vós pudésseis vos voltar e vos doar inteiramente ao 
almas", em "não importa qual parte do mundo onde se espera um maior serviço de Deus e uma maior ajuda para as almas” (Loyola, 1991, Const. 304: 468): eis a vocação do jesuíta, nos termos em que a define também o texto das Constituições. Nessa vocação, é pedido de um jesuíta perseverança e obediência. Porém, aquilo que interessa sobremaneira é confirmar a origem divina do chamado (cf. EE. 172).

O que permite uma certeza acerca da origem da vocação é primeiramente um conhecimento seguro de si mesmo, que dá ao jesuíta a possibilidade de, atento aos movimentos da alma, distinguir o que vem de Deus daquilo que vem do Inimigo. Nesse sentido, é necessária também uma atenção ao desenrolar dos pensamentos contíguos aos desejos experimentados: se, no seu prolongamento, desde o princípio se localizam bons fins e uma orientação ao Bem, "é sinal do bom anjo" (Loyola, 1991, EE. 333: 234); do contrário, “é um sinal claro que isso vem do mau espírito” (Loyola, 1991, EE. 333: 234). Essas exames atentos e outros tantos que se seguem no texto dos Exercícios Espirituais, têm por objetivo facilitar o caminho para a eleição. E, nesse ponto, entram, por exemplos, as tópicas “encomendar”, “considerar”, “dar as razões” e “desengano”.

Nas “Seis maneiras de se fazer uma sã e boa eleição”, Inácio lembra que é necessário "pedir a Deus nosso Senhor que ele queira mover minha vontade e colocar na minha alma aquilo que devo fazer (...), refletindo bem e fielmente com minha inteligência" 52 e, além disso, sugere que se deve "considerar, refletindo, quantas vantagens e proveitos decorrem para mim do fato de ter (...) em vista somente o louvor de Deus nosso Senhor e salvação de minha alma" ${ }^{33}$. Ao final desse trabalho, "olharei para qual lado a razão inclina mais" ${ }^{54}$ : "É, portanto, após uma maior moção da razão, e não após alguma moção dos sentidos, que é necessário tomar a decisão concernente à coisa visada" ${ }^{55}$. Ou seja, para se conhecer bem a origem de um desejo é preciso, primeiro, pedir a Deus a graça da compreensão, quer dizer, "encomendar a coisa a Deus” e, em seguida, ter claras para si as razões que o movem ${ }^{56}$.

O homem deve "se encomendar a Deus”, “confiar-se a Deus” que não o engana, e desconfiar de si mesmo, porque as paixões e os sentidos sempre podem enganar. Porém, nesse "trabalho" o homemsofre "forti, e gravi tentazionni", de tal forma que importa que "veja" e "experimente" que "da se non le può vincere, accioche cosi intenda per isperienza la necessità che hà del favore divino, e diffidi di tutte le sue forze" ${ }^{\text {}}$. Só o

fim para o qual Deus vos criou, sua honra e sua glória, vossa salvação e o socorro de vosso próximo” (Ibid.: 695).

52 EE. 180; Loyola, 1991: 144.

53 EE. 181; Loyola, 1991: 144.

${ }^{54}$ EE. 182; Loyola, 1991: 144.

${ }^{55}$ EE. 182; Loyola, 1991: 144.

${ }^{56}$ Nas Regras Gerais tiradas das Constituições, há um ponto que deixa bastante clara essa dinâmica: segundo o autor, antes de tratar qualquer coisa com o Superior, os jesuítas deves se recolher em oração e, "em seguida, se sentem que devem apresentar o negócio àquele que tem o cargo, que o façam. A outra coisa que devem observar: depois de ter apresentado o negócio de viva voz ou brevemente por escrito (para que não se esqueça), que abandonem todo o cuidado aos superiores e estimem que tudo o que ordenarem será o melhor. Que não repliquem nem façam instâncias, nem por eles mesmo nem por nenhuma outra pessoa, quer os superiores aceitem o que foi pedido ou não. Que todos se persuadam que aquilo que seu superior, estando informado, ordenar será aquilo que convém mais ao serviço divino e a seu maior bem em nosso Senhor” (Loyola, 1991: 614).

${ }^{57}$ Arias, 1600: 45.

81 Paulo Roberto de Andrada Pacheco. Inácio de Loyola ... 67-91 
“favor divino" conferirá eficácia e bons efeitos aos meios empregados em qualquer empresa à qual se dedique o homem ${ }^{58}$. E é, nesse sentido, muito importante que o homem tenha sempre presente - considere - o fim para o qual tanto ele, quanto toda a realidade, foi criada: "considerareil fine perche Dio fatuttelebuone opere, cheè per onore e gloria sua" 59 .

O trabalho do desengano ${ }^{60}$ - de ir à verdadeira fonte que mata a sede e dá sossego ao coração - é um trabalho que requer "a assistência da 'razão', potência suficiente para corrigir os enganos" ${ }^{61}$ dos sentidos. É um trabalho de reconhecimento do essencial, do Ser real de todas as coisas, escondido por trás do variável e instável de sua forma presente. Este trabalho, requer um "olhar" que se estende da origem ao destino de toda a realidade: onde origem e destino coincidem, na medida em que, num dinamismo histórico-teleologicamente-orientado - escatológico, para ser breve -, ambos os pólos remetem ao Doador do Ser, que cria a realidade ininterruptamente - tam Pater nemo - e a leva à sua perfeição final.

Havíamos dito, em outra parte, que é somente "no momento das escolhas definitivas que se observa o sucesso ou o erro" ${ }^{\text {"2 }}$ : uma escolha definitiva - ou uma eleição feita de forma ordenada - coincide com a conformidade com "uma vocação divina" (cf. EE. 172), e a vontade divina nunca engana. Chega-se à esta escolha definitiva, chega-se a fazer uma eleição ordenada, livre dos enganos da paixão, na medida em que se aplicam adequadamente as potências da alma racional: a verdadeira eleição é aquela que tem como fim último a manutenção da relação causal Criadorcriatura. O desengano é, em termos gerais, a aceitação da Graça, o reconhecimento dos "sinais do olhar de Deus, capaz de encontrar na matéria a marca do zelo da Providência" 63 . O desengano, enfim, pode ser descrito como aquela dinâmica de reconhecimento, no desejo, do côncavo infinito que apenas um convexo adequadamente

\footnotetext{
${ }^{58}$ De fato, mais à frente, Arias (1600) afirma: "importa assai che l'huomo ponendo i mezzi necessari non confidi disordinadamente in essi, ma che ponga la sua confidenza perfettamente in Dio, sperando nella sua bontà, che si come gli diede la volontà e forza per porre quei mezzi, che cosi anche darà efficacia all'istessi mezzi, acciò siano di frutto, e habbiano buono effetto operando l'istesso Signore per mezzo loro" (Ibid.: 61-62).

${ }^{59}$ Ibid.: 78. Nestamesmavia, escreve, anos mais tarde, Nieremberg (1645): "El sediento, para satisfacer la sed, no ha de ir sino a una fuente de aguas; y el hombre, para alcanzar sosiego de su corazon, no ha de ir sino a buscar a Dios: el divertirse en otras criaturas, queriendo con ellas apacentar su gusto, no es mas que comer sal con que avive su sed y apetito y se abrase las entrañas” (Nieremberg, 1645: 243).

${ }^{60}$ Delumeau (2003), cita um longo trecho do livro do jesuíta alemão Jeremie Drexel (1581-1638) Tableau desjoyesduparadis - onde a questão do desengano aparece em termos bastante significativos: trata-se de um uso bastante comum da retórica, a desvalorização do terrestre para magnificar o celeste: "Quanto dará alegria e contentamento a visão da beleza soberana de tantos milhares e milhões de maravilhosos objetos que estão no céu! Ali é onde a beleza está como em seu dia e como em pleno triunfo, onde todos os bem-aventurados são sóis e milagres de beleza perfeita, onde finalmente o coro dos anjos e dos homens predestinados é tão maravilhosamente belo no templo de glória que todas as maiores belezas da terra não podem parecer, em comparação, mais que monstruosas feiúras [...]. Ide, portanto, belezas da terra, retirai-vos bem longe de mim! Pois sois apenas máscaras cobertas, corpos fétidos, carcaças podres que, sob o fino véu de pele um pouco branca e vermelha, escondeis mil misérias e mil imundícies! Ide, todo o vosso artifício e vossos disfarces paliativos me causam horror quando contemplo essa eterna e ingênua beleza dos bem-aventurados. Não, não posso suportar a visão desses corpos moribundos e hediondos, que, a pretexto de alguma beleza, são adorados na terra, quando vejo essas belas almas ou esses nobres espíritos que são bem-aventurados no paraíso” (Delumeau, 2003: 387).

${ }^{61}$ Pécora, 1988: 302.

${ }^{62}$ Ibid.: 195.

${ }^{63}$ Ibid.: 313
}

82 Paulo Roberto de Andrada Pacheco. Inácio de Loyola ... 67-91 
infinito seria capaz de preencher: querer preencher a ausência com outros objetos, pelo contrário, é ficar no engano.

Não só se devem aplicar a razão e a vontade neste trabalho, mas também o sentidos - "abre os olhos" -, as potências da alma sensitiva: trata-se da aplicação dos sentidos a que se refere tantas vezes Inácio de Loyola, por exemplo, nos Exercícios Espirituais. A mesma, inclusive, que lhe permitiu, no dia 04 de março de 1544, fazer a seguinte nota no seu Diário de Moções Interiores:

Não sabendo por quem começar, e me fixando primeiramente em Jesus, me parecia que ele não se deixava ver ou sentir claramente, mas de uma certa maneira obscura; e me fixando sobre a Santíssima Trindade, me parecia que ela se deixava sentir e ver mais claramente ou luminosamente. Começando, e continuando com sua divina Majestade, cobri-me de lágrimas, soluços, amor tão intenso que eu tinha a impressão de ser extraordinariamente unido a seu amor tão luminoso e tão doce. De tal forma que esta intensa visita e amor me parecia insigne e excelente comparada às outras visitas ${ }^{64}$.

Os sentidos, para que não se enganem, devem, pois, se voltar a um objeto adequado e, após sua aplicação, se deve considerar a experiência a que se chegou, se deve atingir um juízo racional acerca do sentimento experimentado finalmente. Porém e importa que se compreenda bem - este uso dos sentidos deve ter uma referência de perfeição, para que não se incorra no engano a que são levados naturalmente os sentidos:

Aquele que, no uso de seus sentidos, quiser imitar a Cristo nosso Senhor, se recomendará na oração preparatória, à sua divina Majestade; e após ter considerado cada um dos sentidos, dirá uma Ave Maria ou um Pai Nosso. Aquele que, no uso dos sentidos, quiser imitar Nossa Senhora, se recomendará a ela na oração preparatória para que ela lhe obtenha de seu Filho e Senhor a graça para isso; depois, após considerar cada um dos sentidos, dirá uma Ave Maria ${ }^{65}$.

De tal forma que, quando se fala de sentidos, nesta perspectiva, deve-se entender que não se trata de uma "vidência" como aquela da visio Dei mística, puramente contemplativa e passiva, mas de uma característica iminentemente jesuítica: o fato de que, como o diz Jerônimo de Nadal, o jesuíta é o contemplativo em ação, é o homem da militância missionária, o homem da ação; de tal forma que é na ação, que ele se conhece, é na aplicação de suas potências no contato com a realidade, que ele conhece a si mesmo e a realidade. “Aplicar os sentidos” não é por assim dizer, é concreto.

Além disso, nesta aplicação dos sentidos, o critério para distinguir se o uso foi eficaz é o resultado a que se chega: "Quando a pessoa que se exercita [na aplicação dos sentidos] não encontra ainda o que deseja, como por exemplo lágrimas, consolações etc., é proveitoso fazer uma mudança na comida, no sono e nas outras maneiras de fazer penitência" ${ }^{\prime 66}$.

As "lágrimas” que se experimentam, a “indignidade” e a falta de "virtudes"

\footnotetext{
${ }^{64}$ Loyola, 1991: 348.

${ }^{65}$ EE. 248; Loyola, 1991: 178.

${ }^{66}$ EE. 89; Loyola, 1991: 100-102.
}

83 Paulo Roberto de Andrada Pacheco. Inácio de Loyola ... 67-91 
suficientes para o trabalho missionário que se descobre em si mesmo não são apenas aquela falsa modéstia sentimental a que muitos seriam levados a crer, ou, quem sabe, apenas uma tentativa de persuasão sem verdade - uma pura argumentação sofista com intuito de convencimento pela moção de determinados sentimentos: há, sim, o desejo de moção de determinadas paixões no destinatário (o movere da oratória ciceroniana), mas, na medida do possível, sempre com palavra "plena animi, plena spiritus, plena doloris, plena veritatis"67.

Um outro aspecto deste "conhecimento de si” precisa, antes de avançarmos, ser bem compreendido. Se analisarmos a estrutura dos Exercícios Espirituais, veremos que ele é organizado e pensado como instrumento, grosso modo, com este fim específico: conhecer a si mesmo para bem eleger a vontade de Deus.

A partir de um trecho de Honor delgran patriarca sanIgnacio, escrito por Nieremberg (1645), poderemos compreender melhor esta passagem. Neste livro, o autor, contando a história de santidade do fundador da Companhia de Jesus, chega ao ponto em que começa a descrever a vida de oração de Inácio de Loyola, e escreve:

Para llegar a tan alto punto de oracion, de tal manera domó, y casi extinguio sus afectos san Ignacio, que no parecia hombre, con tal paz de sus passiones sujetas a la razon, tan incontrastable, que pareciaespiritu puro. Cosa tan admirable (...) el perfectissimo dominio que tuvo san Ignacio sobre los movimentosdelscoraçon, y todas sus passiones. Todas las regia, no para mal, sin por necessidad y razon, en quantoservian a la virtud, y que esto en tanto grado, y tan connatural en èl, que jusgaron los Medicosavia mudado totalmente el temperamento, porque como por su natural fuesse ardiente, $\mathrm{y}$ colerico, y como un fuego, le calificavam por frio, y flematico; y no era sino que trocòcondicion, transformandosesegun la condicion del cuerpo en Christolesus, su amado, dexando de ser colerico por ser manso, y humilde de coraçon, como de si dize el mismo Señor ${ }^{68}$.

Só chega a “domar os afetos" aquele que se conhece, que sabe como se movem suas paixões, aquele que percorreu a topografia de sua alma como quem, com a ponta do dedo, assinala num mapa, os caminhos e descaminhos que deverá percorrer. Só chega a "vencer-se a si-mesmo e ordenar sua vida sem se decidir por nenhum vínculo que seja desordenado" 69 o homem que, como "princípio e fundamento", sabe que "é criado para louvar, reverenciar e servir a Deus nosso Senhor e, assim, salvar sua alma" (cf. EE. 23), e que, se dedicando a uma série de práticas e exercícios espirituais, conhece a si mesmo - sua alma - como a um livro aberto e como a palma de sua mão.

Numa edição dos Exercícios Espirituais, publicada na França, em 1673, pela casa editorial “chez Michael Cnobbaert, a L'enseigne de S. Pierre”, encontramos diversas ilustrações que ajudam o exercitante no trabalho de compositio loci. Entre as figuras, encontram-se as seguintes:

\footnotetext{
${ }^{67}$ Cicéron, 1966: 36.

${ }^{68}$ Nieremberg, 1645: 40-41.

${ }^{69}$ EE. 21; Loyola, 1991: 62.
} 


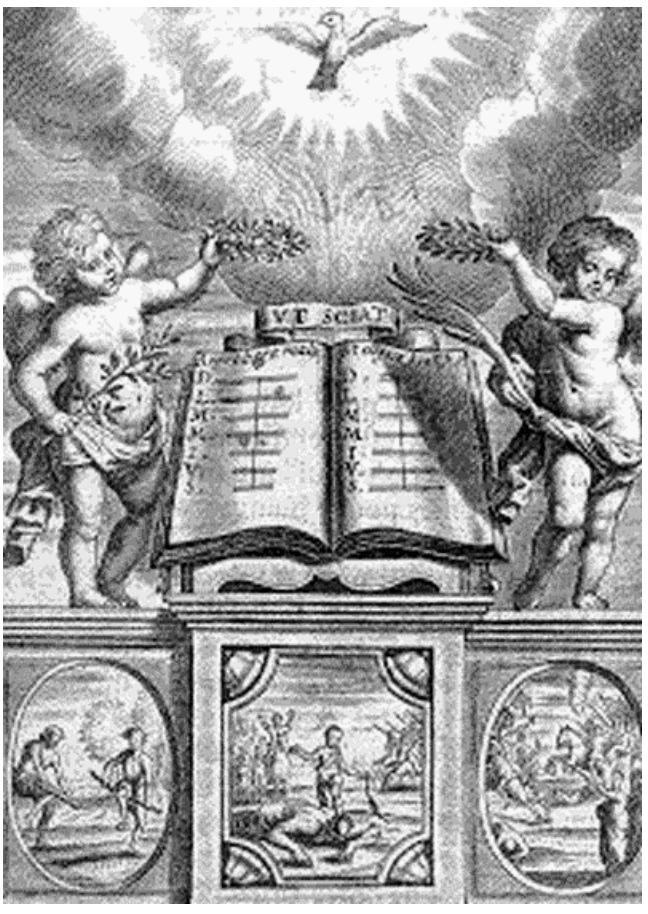

Fig. 01 - O Exame Particular.

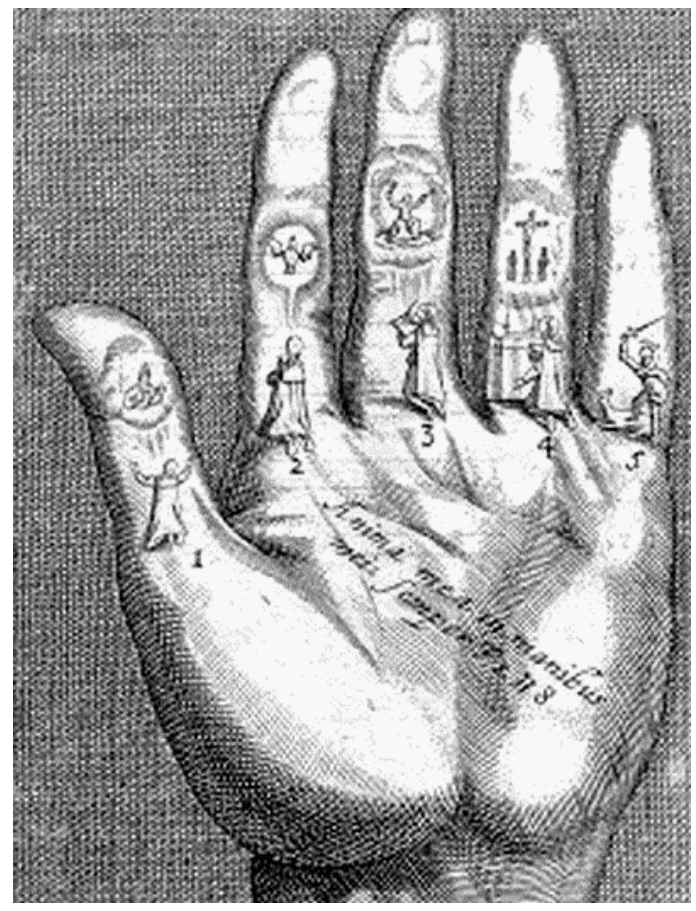

Fig. 02 - O Exame Geral.

Ut sciat, diz o cabeçalho do livro (Fig. 01): "para conhecer". Anima mea in manibusmeissemper, diz a frase anotada na palma da mão (Fig. 02), que representa os cinco pontos referentes à "maneira de fazer o exame geral"70: "minha alma está sempre em minhas mãos"71. Enquanto que o Exame Particular se refere àquele cuidado cotidiano com um "pecado particular ou defeito que se quer corrigir ou emendar" 72 , implicando a constante aplicação das faculdades todas da alma neste conhecimento - do nível vegetativo ao racional; o Exame Geral repassa, um a um, os pecados todos - do pensamento, da palavra e da ação - que se pode cometer. Conhecer-se a si mesmo quer, pois, dizer apenas conhecer sua capacidade de pecado? Não, se se compreende que por meio deste conhecimento - que é o início apenas, a Primeira Semana, dos Exercícios Espirituais - o homem se purifica a fim de melhor entrar nos exercícios que serão propostos em seguida. O homem não só se purifica, mas se desengana e evita seja o excessivo amor próprio, seja a desconsideração de sua própria natureza, que "nos impede[m] a verdadeira liberdade do puro serviço divino"73.

\footnotetext{
${ }^{70}$ Cinco são os pontos: “o primeiro ponto: dar graças a Deus nosso Senhor pelos benefícios recebidos. O segundo: pedir a graça de conhecer seus pecados e de os rejeitar. O terceiro: pedir conta à sua alma, desde a hora em que se levantar até o presente exame, hora após hora, ou período após período, primeiro dos pensamentos, depois das palavras, depois das ações, segundo a mesma ordem que foi indicada para o exame particular. O quarto: pedir perdão das faltas a Deus nosso Senhor. O quinto: formar o propósito de se emendar com sua graça” (EE. 73; Loyola, 1991: 76).

${ }^{71}$ Sl 119,109.

${ }^{72}$ EE. 24; Loyola, 1991: 64.

${ }^{73}$ Aquaviva, 1583: 5.
} 


\section{Educar a obediência para educar â liberdade}

Eleger, mais que fazer escolhas conforme um desejo particular, é, deliberadamente, se lançar ao continuum que, partindo do "conhecimento de si", passa pelo conhecimento da vontade de Deus, para chegar à sua atualização na vida pessoal: o jesuíta, indiferente ao modo e às condições de realização da vontade de Deus, se faz instrumento da glória de Deus, se torna um modelo imitável, na medida em que também imita o exemplo de realização de sua própria humanidade - o próprio Cristo -, tornando-se, finalmente, alguém em quem se pode reconhecer a "Majestade Divina” mesma: divinaenaturae consortes.

O Relato do Peregrino Inácio é bastante significativo. Apesar de o topos “indiferença” não constar uma única vez sequer, é interessante notar como Inácio se portava ante o desejo que sentia e a maneira de realizar esse desejo: por exemplo, na decisão de ir a Jerusalém. Tendo encontrado dificuldade em permanecer em Jerusalém, em 1523, Inácio que andava com a certeza de que Deus queria que estivesse ali, resolve sair furtivamente do grupo de peregrinos a fim de rever a pedra de onde Cristo ascendeu aos céus. Pelo que consta, Inácio precisava ter clara a posição dos pés de Jesus (de que lado se encontrava o pé esquerdo e de que lado o direito) impressos na pedra (segundo a tradição, ficaram impressas duas marcas na pedra), a fim de ler nelas algum sinal positivo da vontade de Deus. Mesmo que todos os sinais anteriores (a negação do Provincial dos monges responsáveis por alguns dos lugares santos e a ameaça de excomunhão, os perigos de andar sem um guia turco, a interdição de entrar no Monte das Oliveiras para ver as pegadas de Cristo etc.) mostrassem claramente a impossibilidade de permanecer e a necessidade de ir-se, Inácio manteve firme o desejo de permanecer, baseado na certeza a que chegou a partir da autorização do Papa e da chegada a Jerusalém, não obstante tudo o que havia conspirado até então para que não chegasse. Haveria para ele, portanto, algo ali que o Senhor queria lhe dizer. O que nos parece antes uma "teimosia" ou mesmo uma "desobediência", na "experiência-modelo" de Inácio pode ser entendido como "indiferença” desde que se compreenda o movente que está por trás desta atitude: conhecer a vontade de Deus e ajudar as almas. Nesse sentido, ele se encontra verdadeiramente "indiferente", na medida em que não tem medo do que se apresenta como obstáculo, mas vai até o fim do mínimo sinal que encontrou.

É essa mesma atitude que o move logo após sua conversão, quando decide sair como soldado em defesa de Cristo e vai se preparando desde Manresa até Paris, se dedicando aos estudos, enfrentando as acusações da Inquisição de que era um "alumbrado", aplicando os Exercícios Espirituais, entabulando conversas devotas e edificantes: é indiferente a maneira como realizará o desejo inicial de ajudar as almas e permitir a maior glória de Deus, o importante é que em tudo se realize esse desejo até o fim. Esse mesmo desejo que fica, dia após dia, mais claro, na atenção aos sinais que lhe são dados pela realidade: encontros que faz, intuições que tem, graças que recebe, compreensões e visões que tem etc. Em Inácio, a "indiferença” é experimentada até as últimas consequências, até o ponto em que, parafraseando São Paulo, se pode dizer que Inácio vive, mas não ele, é Cristo quem vive nele ${ }^{74}$. A “indiferença”, como o afirma Fernández-Martos (1991), em Inácio, é diferenciação e identificação: diferenciação da realidade e identificação total com Cristo.

Enfim, toda “obediência”, toda “indiferença”, toda “mortificação” e penitência, todo exercício de ordenação das paixões visa o fim do Instituto da Companhia de Jesus

\footnotetext{
${ }^{74}$ Cf. Ga 2,20.
} 
expresso no inúmeras vezes repetido mote jesuítico ad maiorem Dei gloria. Uma a uma, as referências ao mote retomam a "experiência-modelo" de Inácio, o homem que, atento primeiramente a si, se coloca diante do concreto da multiplicidade humana, para propor a cada um dos jesuítas o fim mesmo de suas vidas; ou, para usar a expressão de Nadal, o "contemplativo em ação", desejoso de amar e servir em tudo a "su divina Majestad", que, obediente ao real, se dispunha com a mesma obediência à Vontade de Deus, que tantas vezes pediu e se empenhou para conhecer; o homem disponível ao que o Papa, Vigário de Cristo na terra, exigisse; sempre atento a que se cumprisse um verdadeiro serviço de colaboração com a missão de Cristo, de forma a poder ser mais útil ao bem dos homens e, assim, dar maior glória a Deus.

\section{Consolados porque educados à liberdade}

Com o que apresentamos até aqui, temos elementos suficientes para pensar acerca da experiência de consolação: se corolário ou não de uma vida vivida como adesão à vontade de Deus; se termo ou não de uma vida de busca, de constante "peregrinação", de incessante trabalho de desengano do mundo, de olhar para o fundo da realidade; se resposta decisiva à expectativa de uma visão "beatífica”, quando "então, veremos face a face" ${ }^{75}$ e seremos infinitamente felizes e transfigurados; se satisfação, se perfeição conquistada finalmente; se algo apenas do além-vida ou experiência possível no aqui-agora; são hipóteses que se verificarão na medida em que compreendermos adequadamente o significado do uso deste lugar-comum entre os jesuítas do XVI-XVII, na medida em que descrevermos, com os elementos apropriados, a "gramática" que sustenta esse uso particular da tópica em questão.

Havíamos dito anteriormente que a educação do homem, na perspectiva inaciana, é pensada como guia que conduz o jesuíta através da realidade, objetivando aquela consolação final em direção à qual se movem originalmente todos os homens. Na edição ilustrada dos Exercícios Espirituais (1673) a que nos referimos acima encontramos uma figura que descreve bem esta experiência (e a descreve tomando como referência, mais uma vez, a "experiência-modelo" de Inácio de Loyola que relata ter contemplado a corte celeste, na Glória, com a Santíssima Trindade).Poder-se-ia refutar que esta "consolação" perfeita, que só virá quando "veremos face a face”, obsta o dinamismo descrito até aqui, protelando a "experiência de liberdade”, impingindo-a para um futuro tão distante quanto o próprio fim da vida, ou tão distante quanto as Índias além-mar. No entanto - e são os jesuítas, mais uma vez, a nos dizer o contrário -, esta é uma experiência hic et nunc, "já e ainda não”: o gosto, aqui e agora, da eternidade futura, como o dizem Pedro Ruiz e Diego de Salcedo em suas Indipetae:

Y para que mas clara noticia tenga Vuestra Paternidad de mis deseos me parecio convenir dar quentaasi de la perseverancia en ellos tanto tiempo a como del consuelo que Nuestro Señor me comunica en renovarlos a menudo que cierto es grande y asi todas las veces que oygo tratar destas cosas y especialmente de persecuciones y trabajos que padecen los nuestros en aquellas partes siento en mi un nuevo fervor y una nuebaalegria y me confirmo mucho mas en mis deseos ${ }^{76}$ - escreve Ruiz, no dia 29 de julho de 1593.

\footnotetext{
${ }^{75} 1$ Cor 13,12 .

${ }^{76}$ ArchivumRomanumSocietatisIesu.IndipetaeHispanae, FondoGesuitico 758, carta n. 188.
} 
Desde el principio, que entre en la Compañia me dio Nuestro Señor siempre deseos de ir alas Indias, tanto que quandoestavaenel noviciado y se leian las cartas de Japon y otras partes de los Padres, me consolava mucho de oyelas, y me regozijava interiormente pareciendome que yo me hallariaalla con ellos conviviendo, y me crecian los deseos, y aora que esta movida el agua son muy grandes ${ }^{77}$ - relata Salcedo, em carta que escreve no dia 31 de maio de 1594.

Assim descrita, a "consolação" coincide com o que se disse acerca da "felicidade", no sentido de que se trata de um reconhecimento do Sumo Bem - o "Criador e Senhor" do homem - ao mesmo tempo em que carrega consigo um empenho de "amor", um se deixar mover em direção às "coisas celestes e à salvação própria da alma”, e também o consequente corolário - a "alegria interior” e o "repouso e paz" - de todo esse dinamismo de contemplação no real dos sinais da misteriosa presença do Criador, e de ação ordenada ao serviço e louvor desta mesma Presença - tudo isso parte do reconhecimento da vocação última do homem ${ }^{78}$.

Se a vontade é forçada, o homem perde a liberdade ${ }^{79}$ : apenas aplicando-a livremente, numa obediência de entendimento, cheia de razões, o homem (cor)responderá adequadamente ao chamado de Deus para a sua vida e alcançará sua realização e “consolação" definitivas, experimentando-as ainda nesta vida ${ }^{80}$. Somente oferecendo seu entendimento, liberdade e vontade a Deus, o homem pode chegar a dizer aquele fiat ergo voluntas tua em todas e em cada coisa e gesto, de todos e em cada modo em que agir, sempre visando o "único necessário”.

E no que consiste esta liberdade do homem? Nieremberg (1957) responde assim: "En esto está la libertad de los hijos de Dios: el desprecio del mundo, la tranquilidad del ánimo, la conformidad con la voluntad divina, la verdadera prudencia; y es fundamento de toda virtud mirar que no nacimos sino para servir a nuestro Creador solamente" ${ }^{\text {, }}$. O que mais poderia descrever este estado de liberdade, em que o homem, enfim, está constantemente amando a Verdade (que é "a base e o fundamento imóvel” ${ }^{82}$ de toda

\footnotetext{
${ }^{77}$ ArchivumRomanumSocietatisIesu.IndipetaeHispanae, FondoGesuitico 758, carta n. 191.

${ }^{78}$ Inácio lembra também, no EE. 177, falando dos "Três tempos para fazer, em cada um deles, uma sã e boa eleição" que "o terceiro tempo é tranquilo: considerando inicialmente porque o homem nasceu, quer dizer para louvar Deus nosso Senhor e salvar sua alma, e desejando isso, escolhe-se, como meio, uma vida ou um estado que se situa no interior da Igreja, a fim de encontrar nisso uma ajuda para o serviço de seu Senhor e a salvação de sua alma. Digo um tempo tranquilo: quando a alma não está agitada por diversos espíritos e usa de suas faculdades naturais, livre e tranquilamente” (Loyola, 1991: 142).

${ }^{79}$ Cf., por exemplo, Nieremberg (1657). Também Rodriguez (1834) explica que a obediência e os demais votos não tiram a liberdade, apenas a aperfeiçoam e completa dizendo, com Santo Anselmo, que "peccare non est libertas, necparslibertatis; peccare est potius non posse, quam posse: quincumqueenin facit, quod sibi non expedit, quantòmagis hoc potest, tantòmagisadversitas, et perversitaspossunt in illum: Poder pecar, y poder usar mal de lalibertad, no es perfeccion, sino imperfeccion y miseria; ese no es poder, sino flaqueza y enfermidad”(Rodriguez, 1834: 100).

${ }^{80}$ Sanchez (1607) diz que, diante do chamado de Deus, o homem deve dizer como Santo Agostinho "Senhor dai-me o que me pedis, e vos peço o que vos agrada" (Sanchez, 1607: 226, tradução nossa). Este “querer o querer de Deus” é o que faz com que Ele "nos guie para onde é mais necessário” (Ibid.: 226, tradução nossa) e experimentar o cêntuplo prometido no aqui e agora de sua vida.

${ }^{81}$ Nieremberg, 1957: 249.

${ }^{82}$ Nieremberg, 1657: 475, tradução nossa.
} 
felicidade que anseia)? Segundo Nieremberg (1657), deve-se enumerar também o uso mesmo da "Razão", que dá "Ser à Verdade", "vem do Céu”, "procede de Deus, como de sua primeira e natural Origem" ${ }^{83}$; a "Razão" que traz repouso e facilidade, que "transforma todos seus espinhos em rosas", sempre porém com a "assistência do Céu", pois ela "sem dúvida tem necessidade da Graça; de onde deve lhe vir seu maior e mais seguro socorro" ${ }^{\text {. }}$.

A experiência de “consolação" - presente, passada ou futura (experiência, memória ou esperança) -, nas cartas Indipetae, parece ser a indicação daquela felicidade a que se destinam todos os homens, segundo esta antropologia filosófica. A experiência de "consolação", como termo deste dinamismo que vimos descrevendo, é o feliz resultado de uma vida de atenção à realidade tanto do mundo que rodeia o jesuíta - um mundo "sacramental" (Pécora, 1994) -, quanto do mundo que esconde dentro de si - a analogia com o Mistério, o Alfa e Ômega. A experiência de "consolação" é o efeito daquela "obediência", que nada mais é que adesão ao fim último, identificado no trabalho de "conhecimento de si” e de atenção ao mundo e aos demais homens.

\section{Referências}

Agostinho, Santo (1991), A cidade de Deus, (2 vols.), Lisboa: Fundação CalousteGulbenkian.

Agostinho, Santo (1994), A Trindade, São Paulo: Editora Paulus.

Aquaviva, Claudio (1583), Lettera del Nostro Padre Generale Claudio Acquaviva. Sopra la Rinovatione dello spirito à Padri \& Fratelli della Compagnie.29/09/1583, Roma.

Aquino, Tomás de (1947), Suma Teológica, I Parte, Questões 75-83: Do homem considerado na sua alma, São Paulo: GráficaSiqueira.

Arias, Francisco (1600), Profitto spirituale, nel qual s'insegna à fare acquisto delle virtù, \& progresso nello spirito. Del M.R.P. Francesco Arias della Compagnia di Giesu. Tradotto della lingua Spagnuola, dal Cavaliere Fra Giulio Zanchini da Castiglionchio, Milano: Stampa del q. Pacifico Pontio, Impressore Archiepiscopale.

ARSI, IndipetaeHispanae, FG 758, carta n. 188.

ARSI, IndipetaeHispanae, FG 758, carta n. 191.

Cardoso, Armando (1977), Introdução. Em: Loyola, Inácio (1977). Diário Espiritual. São Paulo: Ed. Loyola.

Certeau, Michel de (1982), La fable mystique, 1: XVIe - XVIIe siècle, Paris: Gallimard.

Cicéron, M. T. (1966), De l'orateur. Livredeuxième, Paris: Société d'édition "Les BellesLettres”.

Delumeau, Jean (2003), O que sobrou do paraíso? São Paulo: Companhia das Letras.

\footnotetext{
${ }^{83}$ Ibid.: p. 473, tradução nossa.

${ }^{84}$ Ibid.: 377-378, tradução nossa.
} 
Fernández-Martos, José Maria (1991), La incorporación de la realidad como clave del cambio en los Ejercicios Espirituales. EmAlemany, Carlos e Garcia-Monge, José A. (ed.) (1991). Psicologia y Ejercicios Ignacianos (vol I): la transformación del yo en la experiencia de Ejercicios Espirituales, Bilbao: Mensajero e Sal Terrae.

García-Mateo, Rogelio (1998), Fuentes filosófico-teológicas de los ejercicios según el currículum académico de su autor. Em: Plazaola, Juan (ed.) (1998). Las fuentes de los Ejercicios Espirituales de San Ignacio. Actas del Simposio Internacional (Loyola, 15-19 septiembre 1997), Bilbao: Ediciones Mensajero.

Guibert, Joseph de (1953), La spiritualité de la Compagnie de Jésus: esquissehistorique. EmBibliothecaInstitutiHistoriciSocietatisIesu (Vol. IV), Romae: IHSI.

Loyola, Ignace de (1991), Écrits, Paris: Desclée de Brouwer; Bellarmin (Collection Christus, 76, Textes).

Marin, Louis (1996), Le Récit, réflexionsurun testament. Em Marin, Louis (1999). L'écriture de soi: Ignace de Loyola, Montaigne, Stendhal, Roland Barthes (pp. 137-155), Paris: PressesUniversitaires de France.

Massimi, Marina (2001), Identidade, Tempo, Profecia na visão de Padre Antônio Vieira. Memorandum, 1, 13-32. Retirado em 10/10/01, do World Wide Web: http:// www.fafich.ufmg.br/ memorandum/ artigos01/ massimi01.htm.

Massimi, Marina e Prudente, André Barreto (2002), Um incendido desejo das Índias... São Paulo: Ed. Loyola.

Nieremberg, Juan Eusebio (1645), Honor del gran patriarca san Ignacio de Loyola, fundador de la Compañia de Iesus, en que se propone sua vida, y la de su Dicipulo el apostolo de las Indias S. Francisco Xavier. Con la milagrosa Historia del admirable Padre Marcelo Mastrilli, y las noticias de grand multitud de Hijos del mismo S. Ignacio, varones clarissimos en santidad, dotrina, trabajos, y obras maravillosas en servicio de la Iglesia, Madrid: Maria de Quiñones.

Nieremberg, Juan Eusebio (1657), L'art de conduire la volonté selon les precepts de la morale ancienne \& Moderne, tirez de Philosophes Payens \& Chrestiens. Traduit du latin de Jean Eusebe de Nieremberg, Paraphrase \& de beaucoup enrichy par Louÿs Videl, de Dauphiné. Dedié à Monsieur de Lionne, Conseiller d'Estat ordinaire \& secretaire des Commandemets de la Reyne Regente, Paris: Chez Jean Pocquet.

Nieremberg, Juan Eusebio (1957), Obras escogidas del R. P. Juan Eusebio Nieremberg.Em E. Zepeda-Henriquez (ed.), Biblioteca de Autores Españoles, desde la formación del lenguaje hasta nuestros dias (Tomo 103), Madrid: Ediciones Atlas.

O’Malley, John W. (1999), I primi gesuiti. Milano: Vita e Pensiero.

Pécora, Alcir (1988), O demônio mudo. Em Novaes, Adauto (org.) (1988). O olhar (pp. 301-316), São Paulo: Companhia das Letras.

Pécora, Alcir (1994), Teatro do Sacramento: a unidade teológico-retórico-política dos sermões de Antonio Vieira, São Paulo: EDUSP.

Pécora, Alcir (1998), Lessermonsfunèbresdu padre Vieira. Em Mattoso, Katia de 
Queiroz (org.) (1998), Naissance du Brésil moderne (pp. 194-202), Paris: Presses de l'Université de Paris-Sorbonne.

Pécora, Alcir (1999), Cartas à Segunda Escolástica. Em: Novaes, Adauto (org.) (1999). A outra margem do Ocidente (pp. 373-414), São Paulo: Companhia das Letras.

Rodriguez, Alonso (1834), Ejercicio de perfeccion y virtudes cristianas, su autor el Padre Alonso Rodriguez de la Compañía de Jesus, natural de Valladolid. Dividido en tres partes. Parte tercera. De varios medios para alcanzar la virtud y perfeccion. Nueva Impression, Barcelona: Imprenta de D. Valero Siena y Marti.

Sanchez, Pedro (1607), Le Royaume de Dieu, et le vray chemin pour y parvenir. Composé en Espagnol par le Pere P. Sanchez, Docteur de la Compagnie de Iesus. Traduit en François, par F. Guillaume Levite, de l'Ordre des Predicateurs, Paris: Chez Adrian Beys. 